\title{
Measuring Leanness and Agility of Job Shops: A Rating Scale Based on Expert Consensus
}

\author{
Zaki Kuruppalil \\ Engineering Technology \& Management, Ohio University, Athens, USA \\ *Corresponding author: kuruppal@ohio.edu
}

\begin{abstract}
The importance for job shops in manufacturing spectrum is increasing as the market requires low volume, high quality, custom and specific products. With global competition towards customization, job shops are striving to streamline their operations for better yield and exceed customer expectations by shorter speed to market and maintaining budgetary confinements of customer. In that scenario, both lean and agile manufacturing strategies are important to job shops for improving efficiencies and responding to rapidly changing customer needs. This paper presents a rapid assessment tool for job shops to determine where they stand in terms of exhibiting lean and agile characteristics.
\end{abstract}

Keywords: lean, agile, job shop, leanness, agility

Cite This Article: Zaki Kuruppalil, "Measuring Leanness and Agility of Job Shops: A Rating Scale Based on Expert Consensus.” Journal of Business and Management Sciences, vol. 6, no. 3 (2018): 112-117. doi: 10.12691/jbms-6-3-8.

\section{Introduction to Job Shops}

Job shops are manufacturing companies who make to order a variety of products in relatively low numbers and high variety in batch lots by the use of various generalpurpose standard machine tools or machining centers [1]. Because of batch processing, the possibility of waste or non-value-added activities occurring in their operations are relatively high. Conner compares job shops to restaurants where a chef will cook a piece of steak only after receiving the order [2]. Job shops are likely to have hundreds of part numbers and can never accurately predict their future orders. Considering the unpredictable nature of business, turnaround time in order completion is critical in their business success. The importance of job shops is increasing as customer demands and market requirements are changing quickly and there is more demand towards customization. The market requires low volume, high quality, custom and specific products. With global competition towards customization, job shops are striving to streamline their operations for better yield and exceed customer expectations by shorter speed to market and maintaining budgetary confinements of customer [3].

\section{Leanness Vs Agility}

Leanness and agility refers to two different concepts even though there is some overlap between the two. Lean has its roots tied to Toyota Production System(TPS). Womack and Jones explain that Lean "provides a way to specify value, line up value-creating action in the best sequence, conduct these activities without interruption whenever someone requests them, and perform them more effectively. In short, Lean thinking is 'Lean' because it provides a way to do more with less - less human effort, less equipment, less time, and less space - while coming closer and closer to providing customers with what they really want" [4]. Lean is comprised of operational practices and techniques that could improve efficiencies of the shop floor, provide better utilization of resources (both men and machine, and improved process methods). It emphasizes eliminating manufacturing wastes of overproduction, excess processing, excess motion, waiting to be processed, transportation, defects, and excess inventory. From a job shop perspective, lean manufacturing is more focused on continuously improving the existing manufacturing methods and shop floor practices to eliminate these wastes and create more value to the customer. Leanness have identified to make positive impact on performance measures such as work in process, lead time, cycle times productivity, work place layout and environment and customer service levels [5]. Simmons, Holt, Dennis, \& Walton have reported 600\% increase in throughput and $83 \%$ reduction in defects is just one of the examples to take [6]. In spite of its globally reported successes success stories as an operational strategy, several studies have been conducted regarding lean and its need to be applied differently when it comes to low volume high variety businesses such as job shops [3]. Also, the author is of the opinion that lean's ability as a broader business strategy to address innovation and tapping into opportunities such as niche market is limited.

Whereas Agile Manufacturing originated as result of an effort from Iacocca Institute at Lehigh University to develop a manufacturing framework that could give US 
companies an edge over their worldwide competitors [7] upon a United States Department of Defense (DOD) requested. Agile manufacturing is the ability to thrive and prosper in an environment of constant and unpredictable change by bringing technology, knowledge, skills, resources and people around clearly identified market opportunities [8]. Goldman, Nagel \& Preiss stated that "rapid, relentless and uncertain change is the most unsettling market place reality that companies and people must cope with today" [7] (p.3). The quicker and more effectively changes can be made, the better the enterprise will be able to survive and improve in this environment. It is important to note that agile manufacturing is often misinterpreted as flexible manufacturing. Agility refers to more than flexibility, flexible manufacturing is only one of the few components in agile manufacturing. According to Kidd the concept of Agile Manufacturing is built around the synthesis of a number of enterprises that each have some core skills or competencies which they bring to a joint venturing operation, which is based on using each partner's facilities and resources [7]. For this reason, these joint venture enterprises are called virtual corporations, because they do not own significant capital resources of their own. This helps to make them Agile, as they can be formed and changed very rapidly. The agility that arises can be used for competitive advantage, by being able to respond rapidly to changes occurring in the market environment and through the ability to use and exploit a fundamental resource or knowledge. People need to be brought together, in dynamic teams formed around clearly defined market opportunities, so that it becomes possible to lever one another's knowledge. Through this process is sought the transformation of knowledge into new products and services.

\subsection{Co-existing Strategies}

Lean is more focused on improvising or maximizing the efficiency of resources that are currently existing and within the control of the organization whereas agility deals with preparing the organizations to maximize their advantage in an environment of constant change and unpredictability. Both lean and agile manufacturing strategies can improve business. Agile manufacturing improves the ability of a job shop to quickly respond to market uncertainties, whereas lean manufacturing benefits job shops by improving their operational efficiencies and reduce manufacturing wastes. Agility prepares the organization to take maximum business advantage in a turbulent environment of change and unpredictability. Lean, as a strategy, deals much less with proactive business and exploration of new opportunities. The author is of the opinion that characteristics of agile manufacturing may help businesses fill this gap by encouraging them to become proactive and innovative. Lean as a strategy may be successful in maximizing the efficiency of resources that are within the control of the organization. Lean manufacturing has set practices and techniques which could sometimes serve as means to achieving agile characteristics. Therefore, lean techniques could sometimes serve as a foundation to achieving agility. This implied the need for coexistence of both the strategies.

\subsection{The Need to Measure}

Having concluded, that leanness and agility should coexist, it is important for job shops to know where they stand in terms of leanness and agility to continuously improve their capabilities. However, upon review of literature, only few set of assessment tools exist, specifically for job shops, to measure their leanness and agility. Djassemi has emphasized the importance of job shops to national economy and lack of published material regarding success of these businesses [9]. The closest study found was "Read a Plant -fast" developed by Mr. Eugene Goodson, a professor at University of Michigan Business School. Goodson has developed a Rapid Plant Assessment Tool that could discern a plant's strength and weakness in terms of lean [10]. The assessment tool did not include characteristics of agile manufacturing. Another study of interest was by Rawabdeh that suggested a model for waste assessment in job shop environment [11]. However, the theme of comprehensive tool for job shops was missing from the studies evaluated by the author.

\subsubsection{Underlying Research}

The underlying research for this manuscript was a study conducted by the author comparing key factors of leanness and agility in job shops [12]. The results of that study were published in another manuscript which serves as the primary supporting document for this paper [13]. The author in his study observed that both leanness and agility are important to job shops in terms of eliminating waste and rapidly responding to customer needs. At the end it was concluded that agile and lean manufacturing are two different strategies which address different aspects of a business. They are neither competing nor complementing strategies rather they should be coexisting strategies.

\subsubsection{The Assessment Tool}

The author's study mentioned in the previous section of this document utilized Delphi method to bring collective knowledge of a panel of eleven experts and consonance was reached on the key indicators of leanness and agility. MacCarthy and Atthirawong define Delphi as a systematic, iterative process to elicit a consensus view from a panel of exports [14]. They noted that Delphi process appeared to provide the individual with the greatest degree of individuality or freedom from restrictions on his/her expressions. It avoided the dominant influence of any one member of the group over the others. Two Delphi studies were conducted using two sets of experts (a panel of lean experts and panel of agile experts) and the results were combined. The researcher included in the panel a mix of experts from academia, industry and consultancy. These experts were located geographically in different countries including Israel, United Kingdom and United States. A scale was provided to experts to indicate towards each item as not relevant equaled to 0 , somewhat relevant equaled to 1 , relevant equaled to 2, Very relevant equaled to 3 . The scale was provided under the impression that the experts will rate each indicator with their perception of relative importance. Table 1 has listed agile and lean indicators respectively along with the median scores (required scores) of expert responses as obtained from the Delphi study. 
Table 1. Lean and Agile Indicators for Job Shops, and Required Scores Based on Expert Response

\begin{tabular}{|c|c|c|c|c|c|}
\hline $\begin{array}{l}\text { Item No. } \\
\text { (1) }\end{array}$ & $\begin{array}{l}\text { Domain } \\
(2)\end{array}$ & $\begin{array}{l}\text { Indicators } \\
(3)\end{array}$ & Assessment Question & $\begin{array}{l}\text { Required } \\
\text { score } \\
\text { (5) }\end{array}$ & $\begin{array}{l}\text { Relative } \\
\text { Importance } \\
\text { (6) }\end{array}$ \\
\hline 1 & $\begin{array}{l}\text { Organizational } \\
\text { flexibility and } \\
\text { adaptability }\end{array}$ & Organization flexibility & $\begin{array}{l}\text { The degree to which your organizational structure is flexible } \\
\text { by quickly adjusting its organizational characteristics/ } \\
\text { design to address changing market needs and customer } \\
\text { requirements. }\end{array}$ & 2.50 & $83 \%$ \\
\hline 2 & & $\begin{array}{l}\text { Decentralized } \\
\text { organization }\end{array}$ & $\begin{array}{l}\text { The degree to which your organizational decision making is } \\
\text { decentralized }\end{array}$ & 2.00 & $67 \%$ \\
\hline 3 & & $\begin{array}{l}\text { Virtual enterprising and } \\
\text { rapid partnership }\end{array}$ & $\begin{array}{l}\text { The degree to which your organization is capable of quickly } \\
\text { responding to varying customer demand patterns or new } \\
\text { business opportunities, by forming alliances between entities } \\
\text { with relevant abilities and core competencies within your } \\
\text { company or externally. }\end{array}$ & 2.50 & $83 \%$ \\
\hline 4 & & $\begin{array}{l}\text { Responsiveness to } \\
\text { market change }\end{array}$ & $\begin{array}{l}\text { The degree to which your organization as a whole respond } \\
\text { quickly itself to changes in market needs. (for example, by } \\
\text { adjusting its business and manufacturing strategies) }\end{array}$ & 3.00 & $100 \%$ \\
\hline 5 & & $\begin{array}{l}\text { Quick response to } \\
\text { changing } \\
\text { regulation/legislation }\end{array}$ & $\begin{array}{l}\text { The degree to which your organization is capable of } \\
\text { adapting quickly to changing regulation or legislation. }\end{array}$ & 3.00 & $100 \%$ \\
\hline 6 & $\begin{array}{l}\text { Value creation } \\
\text { and customer } \\
\text { satisfaction }\end{array}$ & $\begin{array}{l}\text { Customer perceived } \\
\text { value }\end{array}$ & $\begin{array}{l}\text { The degree to which your organization recognizes the } \\
\text { benefits of value creation based on customer needs, } \\
\text { customer inputs and customer feedbacks. }\end{array}$ & 3.00 & $100 \%$ \\
\hline 7 & & Focus on value addition & $\begin{array}{l}\text { The degree to which your organization redefines value of } \\
\text { your products with customer satisfaction in mind. }\end{array}$ & 3.00 & $100 \%$ \\
\hline 8 & & $\begin{array}{l}\text { Value stream } \\
\text { identification and } \\
\text { mapping }\end{array}$ & $\begin{array}{l}\text { The degree to which your organization traces and analyzes } \\
\text { every step from design, schedule, order, build, delivery to } \\
\text { maintaining a product and how these steps create actual } \\
\text { value to the customer. }\end{array}$ & 2.00 & $67 \%$ \\
\hline 9 & & $\begin{array}{l}\text { Elimination of non- } \\
\text { value-added activities }\end{array}$ & $\begin{array}{l}\text { The degree to which your organization relentlessly pursues } \\
\text { attempts to eliminate non value-added work. (Work which is } \\
\text { not involved with changing the shape or character of a } \\
\text { product or assembly or work which is not productive or } \\
\text { work that will not contribute to increase the value of your } \\
\text { product to the customer). }\end{array}$ & 3.00 & $100 \%$ \\
\hline 10 & & Flow creation & $\begin{array}{l}\text { The degree to which your organization focus on optimizing } \\
\text { flow of its products across different functional areas rather } \\
\text { than optimizing individual departments. }\end{array}$ & 3.00 & $100 \%$ \\
\hline 11 & & $\begin{array}{l}\text { Kaizen or continuous } \\
\text { improvement }\end{array}$ & $\begin{array}{l}\text { The degree to which continuous efforts for improvements } \\
\text { through kaizen events is a part of your organizational } \\
\text { culture. }\end{array}$ & 3.00 & $100 \%$ \\
\hline 12 & & Rapid delivery & $\begin{array}{l}\text { The degree to which your organization employs means to } \\
\text { improve the service level by meeting or exceeding customer } \\
\text { expectations on delivery date. }\end{array}$ & 3.00 & $100 \%$ \\
\hline 13 & $\begin{array}{l}\text { Proactive } \\
\text { business }\end{array}$ & $\begin{array}{l}\text { Change in business } \\
\text { environment }\end{array}$ & $\begin{array}{l}\text { The degree to which your organization effectively senses } \\
\text { changes in business environment. }\end{array}$ & 3.00 & $100 \%$ \\
\hline 14 & & $\begin{array}{l}\text { Proactive exploration of } \\
\text { new opportunities }\end{array}$ & $\begin{array}{l}\text { The degree to which your organization proactively explores } \\
\text { new opportunities. }\end{array}$ & 2.00 & $67 \%$ \\
\hline 15 & & $\begin{array}{l}\text { Proactive customer } \\
\text { Relationships }\end{array}$ & $\begin{array}{l}\text { The degree to which your organization gathers information } \\
\text { from its customers and detects and anticipates changes in } \\
\text { their requirements and demands. }\end{array}$ & 3.00 & $100 \%$ \\
\hline 16 & & $\begin{array}{l}\text { Development of } \\
\text { effective responses to } \\
\text { new challenges from } \\
\text { competitors }\end{array}$ & $\begin{array}{l}\text { The degree to which your organization has the knowledge of } \\
\text { its competitors and responds to new challenges from them. }\end{array}$ & 3.00 & $100 \%$ \\
\hline 17 & $\begin{array}{l}\text { Management } \\
\text { Commitment }\end{array}$ & $\begin{array}{l}\text { Management } \\
\text { commitment }\end{array}$ & $\begin{array}{l}\text { The degree to which your upper management understands } \\
\text { and supports continuous improvement process. }\end{array}$ & 3.00 & $100 \%$ \\
\hline 18 & & Vision and goals & $\begin{array}{l}\text { The degree to which your organization has a vision and } \\
\text { measurable goals of what the organization needs to become, } \\
\text { and a plan of action for getting there. }\end{array}$ & 3.00 & $100 \%$ \\
\hline 19 & $\begin{array}{l}\text { Leadership and } \\
\text { team effort }\end{array}$ & Leadership \& team effort & $\begin{array}{l}\text { The degree to which you agree that your organization } \\
\text { comprises competent teams and team leaders with personnel } \\
\text { drive, skill and knowledge. }\end{array}$ & 3.00 & $100 \%$ \\
\hline 20 & $\begin{array}{l}\text { Empowering } \\
\text { Workforce }\end{array}$ & $\begin{array}{l}\text { Empowering workforce } \\
\text { with knowledge }\end{array}$ & $\begin{array}{l}\text { The degree to which your organization empowers its work } \\
\text { force with knowledge. }\end{array}$ & 3.00 & $100 \%$ \\
\hline 21 & & $\begin{array}{l}\text { Knowledge } \\
\text { management. }\end{array}$ & $\begin{array}{l}\text { The degree to which your organization generate value from } \\
\text { their intellectual and knowledge-based assets by gathering, } \\
\text { organizing, sharing, and analyzing its knowledge in terms of } \\
\text { resources, practices, documents, and people skills. }\end{array}$ & 3.00 & $100 \%$ \\
\hline 22 & & $\begin{array}{l}\text { Enhancing skill and } \\
\text { knowledge by training }\end{array}$ & $\begin{array}{l}\text { The degree to which your organization enhances the skills } \\
\text { and knowledge of its employees by training. }\end{array}$ & 3.00 & $100 \%$ \\
\hline 23 & & $\begin{array}{l}\text { Rapid adjustment of } \\
\text { people capabilities (skills } \\
\text { and knowledge) }\end{array}$ & $\begin{array}{l}\text { The degree to which your organization has the capacity to } \\
\text { rapidly adjust people's skills and knowledge. }\end{array}$ & 3.00 & $100 \%$ \\
\hline
\end{tabular}




\begin{tabular}{|c|c|c|c|c|c|}
\hline $\begin{array}{l}\text { Item No. } \\
\text { (1) }\end{array}$ & $\begin{array}{l}\text { Domain } \\
(2)\end{array}$ & $\begin{array}{l}\text { Indicators } \\
\text { (3) }\end{array}$ & Assessment Question & $\begin{array}{l}\text { Required } \\
\text { score } \\
(5)\end{array}$ & $\begin{array}{l}\text { Relative } \\
\text { Importance } \\
\text { (6) }\end{array}$ \\
\hline 24 & & Multi skilled people & $\begin{array}{l}\text { The degree to which your organization cross trains its } \\
\text { employees for multi-tasking. }\end{array}$ & 3.00 & $100 \%$ \\
\hline 25 & & $\begin{array}{l}\text { Adaptive evaluation and } \\
\text { reward metrics }\end{array}$ & $\begin{array}{l}\text { The degree to which your organization evaluate its } \\
\text { employees and rewards them based on their performance } \\
\text { and behavioral changes that contribute to organizational } \\
\text { improvement. }\end{array}$ & 2.50 & $83 \%$ \\
\hline 26 & & Employee satisfaction & $\begin{array}{l}\text { Employee satisfaction: The degree to which you agree that } \\
\text { your organization encourages employee satisfaction. }\end{array}$ & 3.00 & $100 \%$ \\
\hline 27 & & Lean culture & $\begin{array}{l}\text { Lean culture: The degree to which your organization } \\
\text { educates the work force about the value of a lean } \\
\text { transformation and encourages them to embrace practices } \\
\text { and behaviors that support it. }\end{array}$ & 3.00 & $100 \%$ \\
\hline 28 & $\begin{array}{l}\text { Information } \\
\text { integration }\end{array}$ & $\begin{array}{l}\text { Internal and external } \\
\text { integration of } \\
\text { information }\end{array}$ & $\begin{array}{l}\text { The degree to which your organization has been successful } \\
\text { in integrating information internally (within the functional } \\
\text { areas) and externally (customers and suppliers) for the } \\
\text { purpose of facilitating planning, control, co-ordination, } \\
\text { analysis and decision making. }\end{array}$ & 2.50 & $83 \%$ \\
\hline 29 & $\begin{array}{l}\text { Technology and } \\
\text { innovation }\end{array}$ & $\begin{array}{l}\text { Investment in } \\
\text { appropriate technology }\end{array}$ & $\begin{array}{l}\text { The degree to which your organization has the appropriate } \\
\text { technology to keep itself competitive in the market. }\end{array}$ & 2.50 & $83 \%$ \\
\hline 30 & & $\begin{array}{l}\text { Encouraging and } \\
\text { investing in innovation }\end{array}$ & $\begin{array}{l}\text { The degree to which your organization encourages and } \\
\text { invests in R \& D that could improve opportunities for } \\
\text { system wide innovation, learning and improvement. }\end{array}$ & 2.50 & $83 \%$ \\
\hline 31 & $\begin{array}{l}\text { Product } \\
\text { development } \\
\text { and production } \\
\text { capability, } \\
\text { flexibility, and } \\
\text { adaptability } \\
\end{array}$ & $\begin{array}{l}\text { Reconfigurable } \\
\text { production/process } \\
\text { technology }\end{array}$ & $\begin{array}{l}\text { The degree to which your organization has reconfigurable } \\
\text { production/ process technology that has the capability to } \\
\text { rapidly adopt new methods, techniques, technologies and } \\
\text { processes in response to changing market needs. }\end{array}$ & 2.50 & $83 \%$ \\
\hline 32 & & $\begin{array}{l}\text { Fast product } \\
\text { development cycle }\end{array}$ & $\begin{array}{l}\text { The degree to which your organization is capable of fast } \\
\text { product development cycles (quick time to market). }\end{array}$ & 2.00 & $67 \%$ \\
\hline 33 & & $\begin{array}{l}\text { Product model flexibility } \\
\text { capability }\end{array}$ & $\begin{array}{l}\text { The degree to which your plant has the flexibility to cope } \\
\text { with a wide range of products. }\end{array}$ & 2.00 & $67 \%$ \\
\hline 34 & & $\begin{array}{l}\text { Product volume } \\
\text { flexibility capability }\end{array}$ & $\begin{array}{l}\text { The degree to which your plant has the flexibility to cope } \\
\text { with a wide range of batch sizes. }\end{array}$ & 2.50 & $83 \%$ \\
\hline 35 & & Mass customization & $\begin{array}{l}\text { The degree to which your organization is progressing } \\
\text { towards meeting individualized needs of your customer } \\
\text { while keeping unit cost low. }\end{array}$ & 2.50 & $83 \%$ \\
\hline 36 & & Rapid prototyping & $\begin{array}{l}\text { The degree to which rapid prototyping is serving as a means } \\
\text { to expedite the product design process by reducing time to } \\
\text { market. }\end{array}$ & 2.50 & $83 \%$ \\
\hline 37 & & $\begin{array}{l}\text { Developing unique } \\
\text { capabilities and } \\
\text { characteristics difficult } \\
\text { to copy }\end{array}$ & $\begin{array}{l}\text { The degree to which your organization has developed } \\
\text { unique capabilities and characteristics difficult to copy. }\end{array}$ & 3.00 & $100 \%$ \\
\hline 38 & & $\begin{array}{l}\text { Faster manufacturing } \\
\text { times }\end{array}$ & $\begin{array}{l}\text { The degree to which your organization continually improves } \\
\text { the manufacturing time of its product. }\end{array}$ & 2.50 & $83 \%$ \\
\hline 39 & $\begin{array}{l}\text { Shop floor } \\
\text { management } \\
\text { and control }\end{array}$ & $\begin{array}{l}\text { Identification of seven } \\
\text { types of wastes }\end{array}$ & $\begin{array}{l}\text { The degree to which your organization takes steps to } \\
\text { identify and eliminate the seven types of waste that could } \\
\text { occur in a job shop. (Waste of over production, excess } \\
\text { inventory, waiting to get processed, transportation, excess } \\
\text { motion, defects, and over processing). }\end{array}$ & 3.00 & $100 \%$ \\
\hline 40 & & Just in time & $\begin{array}{l}\text { The degree to which the materials are processed and moved } \\
\text { in workstations in order to arrive just in time for next } \\
\text { operation. }\end{array}$ & 2.00 & $67 \%$ \\
\hline 41 & & Standard work in process & $\begin{array}{l}\text { The degree to which your organization calculates standard } \\
\text { work in process to maintain the optimal supply of material } \\
\text { to satisfy customer demand at the same time keeping } \\
\text { inventory low. }\end{array}$ & 3.00 & $100 \%$ \\
\hline 42 & & Production leveling & $\begin{array}{l}\text { The degree to which your shop floor management practices } \\
\text { include attempts to balance production quantities and } \\
\text { processing capacities so that customer order is fulfilled. }\end{array}$ & 2.50 & $83 \%$ \\
\hline 43 & & Takt based production & $\begin{array}{l}\text { The degree to which your production is scheduled based on } \\
\text { takt time (maximum time allowed to produce a part based on } \\
\text { customer demand and total daily time available). }\end{array}$ & 2.00 & $67 \%$ \\
\hline 44 & & Visual control & $\begin{array}{l}\text { The degree to which your shop floor has employed visual } \\
\text { means to let everyone know the current status, problems, } \\
\text { deviation from standard of equipments, tooling, people, } \\
\text { product and performance. }\end{array}$ & 3.00 & $100 \%$ \\
\hline 45 & & Five S & $\begin{array}{l}\text { The degree to which your organization practices the Five S } \\
\text { 's of organizing, standardizing, cleaning, developing, and } \\
\text { sustaining a productive work environment }\end{array}$ & 3.00 & $100 \%$ \\
\hline 46 & & Shift start up meetings & $\begin{array}{l}\text { The degree to which shop floor area (may be different } \\
\text { divisions) of your organization has shift start up meetings } \\
\text { for updates or plan day to day activities. }\end{array}$ & 3.00 & $100 \%$ \\
\hline
\end{tabular}




\begin{tabular}{|c|c|c|c|c|c|}
\hline $\begin{array}{l}\text { Item No. } \\
\text { (1) }\end{array}$ & $\begin{array}{l}\text { Domain } \\
(2)\end{array}$ & $\begin{array}{l}\text { Indicators } \\
\text { (3) }\end{array}$ & Assessment Question & $\begin{array}{l}\text { Required } \\
\text { score } \\
\text { (5) }\end{array}$ & $\begin{array}{l}\text { Relative } \\
\text { Importance } \\
\text { (6) }\end{array}$ \\
\hline 47 & $\begin{array}{l}\text { Set up and } \\
\text { process } \\
\text { improvement }\end{array}$ & $\begin{array}{l}\text { Single minute die } \\
\text { exchange (SMED) }\end{array}$ & $\begin{array}{l}\text { The degree to which operators or engineers continuously } \\
\text { improve set up times by utilizing techniques to reduce } \\
\text { machine down times or other quick set up techniques. }\end{array}$ & 2.50 & $83 \%$ \\
\hline 48 & & Standard work & $\begin{array}{l}\text { The degree to which your organization maintains standard } \\
\text { work sheets and encourages operators and engineers to use } \\
\text { collective intelligence to continuously improve the process } \\
\text { (a standard work sheet usually includes cycle time, work } \\
\text { sequence and standard inventory). }\end{array}$ & 3.00 & $100 \%$ \\
\hline 49 & & Process mapping & $\begin{array}{l}\text { The degree to which processes are mapped for analysis and } \\
\text { improvement. }\end{array}$ & 3.00 & $100 \%$ \\
\hline 50 & & $\begin{array}{l}\text { Error proofing (Poke } \\
\text { yoke) }\end{array}$ & $\begin{array}{l}\text { The degree to which error proofing methods or devices are } \\
\text { used in production and inspection processes (that prevents a } \\
\text { defective part from being further processed or any setup that } \\
\text { would prevent incorrect processing). }\end{array}$ & 3.00 & $100 \%$ \\
\hline 51 & & One piece flow & $\begin{array}{l}\text { The degree to which your organization has been successful } \\
\text { in reducing batch sizes by continuously improving set up } \\
\text { times and balancing the lines. }\end{array}$ & 2.00 & $67 \%$ \\
\hline 52 & $\begin{array}{l}\text { Machine } \\
\text { dependability } \\
\text { and reliability }\end{array}$ & $\begin{array}{l}\text { Automation with human } \\
\text { touch (Autonomation or } \\
\text { Jidoka) }\end{array}$ & $\begin{array}{l}\text { The degree to which your machines are automated that it } \\
\text { will shut off automatically when any abnormalities occur? }\end{array}$ & 2.00 & $67 \%$ \\
\hline 53 & & $\begin{array}{l}\text { Total Productive } \\
\text { Maintenance (TPM) }\end{array}$ & $\begin{array}{l}\text { The degree to which operators and maintenance personals } \\
\text { conduct any productive maintenance practices such as } \\
\text { preventive maintenance or periodic inspection to retain } \\
\text { healthy condition of your machines }\end{array}$ & 2.00 & $67 \%$ \\
\hline 54 & $\begin{array}{l}\text { Quality } \\
\text { management }\end{array}$ & $\begin{array}{l}\text { Total Quality } \\
\text { Management (TQM) } \\
\text { principles }\end{array}$ & $\begin{array}{l}\text { The degree to which your organization is practicing TQM } \\
\text { principles. }\end{array}$ & 2.00 & $67 \%$ \\
\hline 55 & & $\begin{array}{l}\text { Statistical Quality } \\
\text { Control (SPC) }\end{array}$ & $\begin{array}{l}\text { The degree to which your organization uses statistical } \\
\text { process control to control and monitor your processes. }\end{array}$ & 2.00 & $67 \%$ \\
\hline 56 & $\begin{array}{l}\text { Supply chain } \\
\text { management }\end{array}$ & Lean enterprise & $\begin{array}{l}\text { The degree to which your supply chain is transparent and } \\
\text { integrated in nature (with your suppliers and customers, you } \\
\text { have shared goals, plans and schedules that mutually } \\
\text { benefits and there is a collective effort towards eliminating } \\
\text { waste and creating value). }\end{array}$ & 2.67 & $89 \%$ \\
\hline 57 & & $\begin{array}{l}\text { Reconfigurable supply } \\
\text { chain and business } \\
\text { partnership }\end{array}$ & $\begin{array}{l}\text { the degree to which your organization have reconfigurable } \\
\text { supply chain and business partnership that could respond } \\
\text { quickly to changing market needs. }\end{array}$ & 2.25 & $75 \%$ \\
\hline 58 & & Supplier selection & $\begin{array}{l}\text { The degree to which your organization is limiting the } \\
\text { number of suppliers and extending partnership and trust with } \\
\text { existing customer with a long-term commitment. }\end{array}$ & 2.33 & $78 \%$ \\
\hline
\end{tabular}

Column 1, is a numerical identification for each indicator. Column 2, represents broader categories or domains of leanness and agility as identified by the author. Column 3, represents description of the lean/agile indicator. Column 4, represents assessment question to be asked while rating eating each indicator. Column 5, represents the median score was renamed as required score as it represented consensus of experts on relevance of each indicator. Any response with a median score below two was omitted as it was indication that most experts considered that particular item below relevance. Column 6, the last column of the table was calculated to represent their relative importance to one another.

Since each of this indicator are weighed differently by the experts, an assessment tool utilizing a radar chart would help job shops assess where they stand in terms of leanness and agility compared to what is stated as required by the experts. This would help to associate each indicator differently based on the relative importance with which it was viewed by the experts. Such a chart is depicted below in Figure 1.

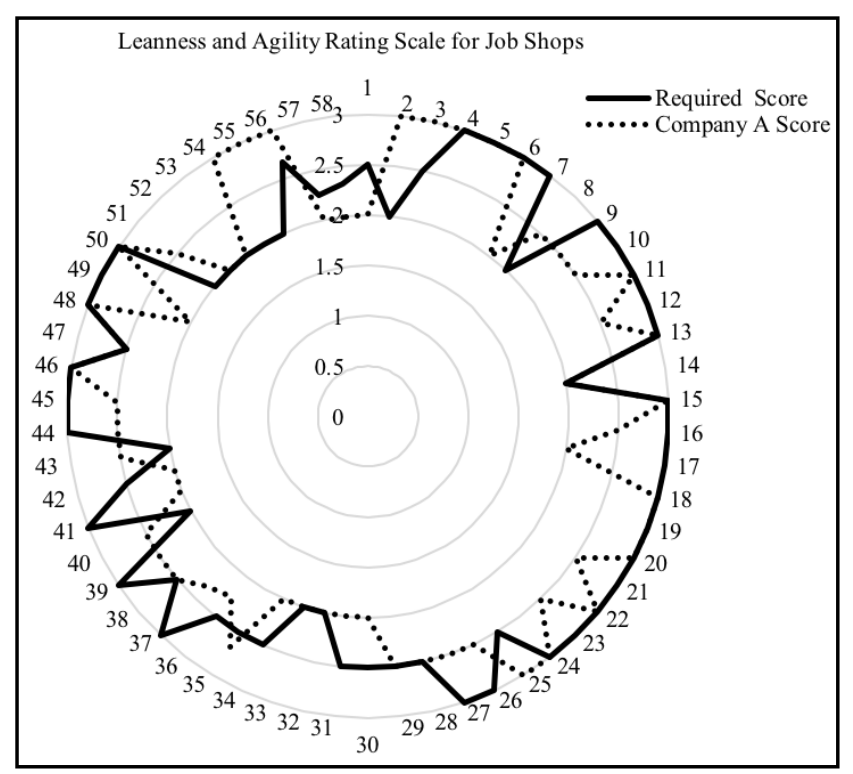

Figure 1. Leanness and Agility Rating Scale for Job Shops 
It should be noted that the company A and its scores mentioned in Figure 1 are hypothetical and was included with the intention of simplifying interpretation of the above rating scale. Each of the numbers 1 through 58 represents corresponding lean or agile indicators mentioned in Table 1. Job shops (such as Company A) could rate on a scale of 0 to 3 (not relevant to the company equaled to 0 , somewhat relevant equaled to 1 , relevant equaled to 2 , Very relevant equaled to 3) to perform a self-analysis of where they stand in terms of leanness and agility compared to expert rating. The scale description could be altered to users convenience as long as relative importance (required score) is un altered.

\section{Conclusions}

The rating scale represented in Figure 1. could be used as an initial assessment tool to identify areas where management focus is needed to improve on leanness and agility. It should be noted this assessment tool is not meant to measure performances of job shops after implementing lean or agile tools and techniques. This tool would simply give an estimate of where a job shop stand in terms of exhibiting lean and agile characteristics. Also, the assessment is generic in nature and the effects of additional factors such as size of job shops, position in supply chain, geographic location could influence the assessment and should be considered as a limitation of this tool. The tool could serve as a quick reference to any company who is interested in knowing what comprises leanness and agility. The indicators listed under agility are generic in nature that could be utilized by other types of businesses in the manufacturing spectrum. The data collected could be analyzed using appropriate statistical techniques to deduce conclusions on the characteristics of the job shop under study. These results of such an analysis could also be utilized to reveal any correlation between lean and agile indicators. The 14 domains of the indicators are of great importance as a quick analysis tool. The comparison of these broader categories, for example, if companies score low in the items under domains "Proactive Business", that could be identified as one of the areas which need attention to improve the business. The scope for future research with the indicators and identifying each of its metrics area abundant. Even though a variety of metrics exist to measure lean related indicators, evaluation metrics for agility related indicators are limited and is open to further research.

\section{References}

[1] Kalpakjian, S., \& Schmid, S. R. (2000). Manufacturing engineering and technology ( $4^{\text {th }}$ ed.). Upper Saddle River, NJ: Prentice Hall

[2] Conner, G. (2001). Lean manufacturing for the small shop. Dearborn, MI: Society of Manufacturing Engineers

[3] Qudrat-Ullah, H., Seo Song B., \& Mills B.L (2012). Improving high variable-low volume operations: an exploration into the lean product development. International Journal of Technology Management, 57(1/2/3), 65.

[4] Womack, J. P., \& Jones, D. T. (1996). Lean thinking: banish waste and create wealth in your corporation. NY, New York: Simon \& Schuster.

[5] Haider, A. \& Mirza, J. (2015). An implementation of lean scheduling in a job shop environment. Advances in Production Engineering \& Management, 10 (1), 8.

[6] Simmons, L., Holt, R., Dennis, G., \& Walden, C. (2010). Lean implementation in a low volume manufacturing environment: a case study. Proceeding of the 2010 Industrial Engineering research Conference.

[7] Goldman, S. L., Nagel, R. N., \& Preiss, K. (1995). Agile competitors and virtual organizations. New York, NY: Van Nostrand Reinhold.

[8] Kidd, P. T. (1994). Agile manufacturing: forging new frontiers. Reading, MA: Addison- Wesley.

[9] Djassemi, M. (2014). Lean adoption in small manufacturing shoops. Attributes and challenges. The journal of Technology, Management, and Applied Engineering, 30 (1), 2-9.

[10] Goodson, E. R. (2002). Read a plant-Fast. Harvard Business Review,80(5), 105-113.

[11] Rawabdeh, H. (2005). A model for the assessment of waste in job shop environments. International Journal of Operations \& Production Management, 25 (8), 800-822.

[12] Kuruppalil, Z. (2007). Leanness and agility in job shops: A framework for a survey instrument developed using the Delphi method. Terre Haute, IN. Indiana State University.

[13] Kuruppalil, Z. (2008). Key Domains of Leanness and Agility in Job Shops. Proceeding of 2008 Internation Conference on Agile Manufacturing.

[14] MacCarthy, B.L, \& Atthirawong, W. (2003). Factors affecting local decisions in an international operation: A Delphi study. International Journal of Operation and Production Management, 23(7/8), 794-817. 